\title{
Kapabilitas Pemerintah Daerah Provinsi Riau: Hambatan dan Tantangan Pengendalian Kebakaran Hutan dan Lahan
}

\section{Geovani Meiwanda•}

\begin{abstract}
Land and forest fires in Riau have occurred since 1998 until last year 2015 by a haze emergency status as a result, causing economic losses, ecological and social aspects. The urgency in this study to see why the Riau provincial government off guard so persistent, because the capabilities of the system and the process will involve considering the fire that occurred not once or twice only. The purpose of this research to know the capabilities being run the Riau provincial government has been in control of who impressed off guard because repeated continuously, and whether factors constraints and defience influencing the capabilities of the Riau provincial government.
\end{abstract}

\section{Keywords:}

capability, forest fire and land.

\begin{abstract}
Abstrak
Kebakaran hutan dan lahan di Riau terjadi sejak tahun 1998 hingga terakhir tahun 2015 dengan status darurat asap. Dampaknya adalah kerugian ekonomi, ekologis serta sosial. Urgensi penelitian ini adalah melihat mengapa Pemerintah Provinsi Riau cenderung lengah sehingga kebakaran hutan dan lahan terjadi terus menerus. Kapabilitas Pemerintah Riau menyangkut sistem dan proses mengingat kebakaran yang terjadi bukan hanya satu dua kali saja. Penelitian ini dilakukan dengan maksud untuk mengetahui kapabilitas Pemerintah Provinsi Riau dalam pengendalian kebakaran hutan dan lahan.
\end{abstract}

\section{Kata Kunci:}

kapabilitas, kebakaran hutan dan lahan.

\section{Pendahuluan}

Kapabilitas Pemerintah Daerah Provinsi Riau selama ini tidak luput dari perhatian terkait kabut asap yang terjadi akibat kebakaran hutan. Masalah ini juga menjadi sorotan bagi negara tetangga, terlebih negara yang letak geografisnya tidak jauh dari Provinsi Riau. Kerugian lintas geografis dan lintas negara

\footnotetext{
- Asisten peneliti di FISIP Universitas Riau. Email: geovani.meiwanda@yahoo.com
}

ini terjadi terus menerus sejak tahun 1998 dan menimbulkan kerugian sosial, ekonomi serta ekologi lingkungan.

Konversi pengembangan lahan perkebunan sawit menjadi penyebab dominan kebakaran hutan dan lahan yang terjadi di Riau selama ini. Ekosistem gambut yang ada di Riau menjadi potensi utama kebakaran menjadi semakin parah. Lahan gambut diubah fungsinya menjadi areal perkebunan, dengan kondisi kering. Sifat lahan gambut jika terbakar 
sulit untuk dipadamkan, karena kedalaman gambut di bawah tanah yang bisa mencapai sepuluh meter. Struktur ekosistem gambut sebetulnya sudah dipahami oleh pemerintah Provinsi Riau, namun kebakaran masih saja terulang.

Kapabilitas pemerintah Provinsi Riau sangat dituntut dalam mengendalikan kebakaran hutan dan lahan. Kapabilitas merupakan bentuk dari kemampuan yang harus dimiliki oleh pemerintah pusat maupun daerah menghadapi tantangan dan masalah yang terjadi dalam dinamika serta perubahan. Kebakaran terus menerus mengindikasikan bahwa Pemerintah Provinsi Riau tidak mampu mengendalikan kebakaran hutan, terlihat dari efeknya yaitu kabut asap. Hal ini menunjukkan bahwa diperlukan sebuah kapabilitas yang baik untuk mengendalikan kebakaran hutan dan lahan penyebab kabut asap. Tentu hal ini tidak luput dari dukungan para stakeholder serta masyarakat Riau sendiri.

Tabel1.menunjukkan kasuskebakaran yang diidentifikasi oleh Polda Riau terhadap beberapa kabupaten/kota di Riau. Data yang dikeluarkan oleh Polda Riau memperlihatkan jumlah kasus kebakaran hutan dan lahan yang terjadi pada tahun 2014-2015. Areal yang terbakar merupakan lahan masyarakat, perusahaan dan areal konsesi milik perusahaan swasta. Seluruh kasus tersebut terkena Undang-undang Republik Indonesia Nomor 32 Tahun 2009 tentang Perlindungan dan Pengelolaan Lingkungan Hidup. Kebakaran hutan dan lahan sudah terjadi jauh sebelum status darurat asap pada bulan Agustus, September dan Oktober 2015.
Sejauh ini upaya yang dilakukan oleh Pemerintah Provinsi Riau, sebagai bentuk nyata dari kapabilitas pengendalian kebakaran hutan dan lahan adalah membentuk posko gabungan. Ketugasannya antara lain memfasilitasi semua upaya pengendalian (tim kesehatan, tim penegakan hukum, juga pemadaman) yang disinergikan dengan pemerintahan tingkat kabupaten. Segala bentuk keterlibatan yang diklasifikasikan dalam hambatan dan tantangan menunjukkan adanya pengaruh kapabilitas Pemerintah dengan kebakaran hutan yang terjadi berulang kali.

Urgensi dari penelitian ini adalah untuk menjawab kapabilitas seperti apa yang dimiliki oleh pemerintah daerah Provinsi Riau dalam mengendalikan kebakaran hutan. Sejauh mana tantangan dan hambatan memberi pengaruh dalam kapabilitas dari pemerintah Provinsi Riau. Kapabilitas akan menjadi sebuah tolok ukur dalam pemahaman yang dimiliki pemerintah daerah Provinsi Riau dalam pengendalian yang telah dilaksanakan selama ini, sesuai dengan keadaan dan tantangan yang selalu berkembang di Riau.

Pemerintah Provinsi Riau menyatakan telah melakukan pengendalian terhadap kebakaran hutan dan lahan yang menyebabkan kabut asap semakin tebal dan mengganggu mobilitas masyarakat, namun kebakaran dan kabut asap tetap muncul kembali. Maka atas dasar tersebut peneliti memiliki dua pertanyaan dalam penelitian ini yakni bagaimana kapabilitas pemerintah daerah dalam pengendalian kebakaran hutan dan lahan di Provinsi Riau yang menyebabkan

Tabel 1.

Jumlah kasus Kebakaran Hutan dan Lahan di Provinsi Riau

\begin{tabular}{|c|c|c|c|}
\hline \multicolumn{4}{|c|}{ Data Karhutla Polda Riau Tahun 2014 Hingga Pertengah Tahun 2015} \\
\hline No. & Tahun & Jumlah Kasus & TP/MO dan Pasar \\
\hline 1. & 2014 & 76 Kasus & $\begin{array}{l}\text { Pasal } 108 \text { dan atau Pasal } 98 \text { Ayat (1) UU RI Nomor } 32 \text { Tahun } 2009 \text { tentang } \\
\text { Perlindungan dan Pengelolaan Lingkungan Hidup }\end{array}$ \\
\hline 2. & Januari-Juli 2015 & 23 Kasus & $\begin{array}{l}\text { Pasal } 108 \text { dan atau Pasal } 98 \text { ayat (1) UU RI Nomor } 32 \text { Tahun } 2009 \text { tentang } \\
\text { Perlindungan dan Pengelolaan Lingkungan Hidup }\end{array}$ \\
\hline
\end{tabular}

Sumber: diolah peneliti 
bencana kabut asap dan sejauh mana hambatan dan tantangan memberi pengaruh terhadap kapabilitas Pemerintah Provinsi Riau dalam mengendalikan kebakaran hutan dan lahan?

\section{Kapabilitas}

Kapabilitas adalah kemampuan organisasi untuk berubah dan mengembangkan prasyarat penting dengan cepat untuk mempertahankan keunggulan kompetitif. Kompleksitas kapabilitas mencerminkan adanya kebutuhan internal untuk menguasai tugas-tugas yang kompleks (Screyogg \& Kliesch-Eberl, 2007).

Kapabilitas organisasi yang didefinisikan oleh The Australian Public Service Commission (2014), yakni:

"Organizational capability can be defined as: "The sum of the expertise of people and the capacity of the organization to apply this expertise". Expertise is the combined of staff and comprises organizational knowledge, skills and human capital. Capacity is how the organization applies its expetise. Capability captures an organisation's potential to achieve outcomes, the effetiveness with which outcomes are achieved and the quality of outputs and outcomes".
Kapabilitas organisasi merupakan kombinasi dari keahlian/kompetensi sumber daya manusia (SDM) dan kapasitas organisasi untuk menerapkan keahlian yang dimiliki SDM-nya, sehingga kapabilitas organisasi lebih dari sekedar sumber daya manusia tapi juga menyangkut "sistem" dan "proses". Dalam Kusumasari, 2014 (Charoenngam \& Leungbootnak, 2005; Diallo \& Thuillier, 2004; Moe \& Pathranarakul, 2006; Newport \& Jawahar, 2003; Perry, 2007; Quarantelli, 1997; Tumer \& Muller, 2004; Youker, 1999) dijelaskan hubungan antara kapabilitas pemerintah dan faktor-faktor penting dalam manajemen bencana.

\section{Faktor Hambatan dan Tantangan dalam Pengendalian Kebakaran Hutan dan Lahan di Provinsi Riau}

Faktor-faktor hambatan dapat dirinci sebagai berikut, yakni pertama, pembagian wewenang kawasan kehutanan (sesuai dengan Peraturan Pemerintah Nomor 38 Tahun 2007 tentang Pembagian Urusan Pemerintahan antara Pemerintah, Pemerintahan Daerah Provinsi dan Pemerintahan Daerah Kabupaten/ Kota). Kedua, keterbatasan alat. Sulitnya memadamkan api kebakaran lahan hutan gambut disebabkan oleh tidak adanya unit

Tabel 2.

Hubungan antara Kapabilitas Pemerintah dan Faktor-Faktor Penting dalam Manajemen Bencana

\begin{tabular}{ll}
\hline \multicolumn{1}{c}{ Kapabilitas } & \multicolumn{1}{c}{ Faktor Penting } \\
\hline Kelembagaan & $\begin{array}{l}\text { Pengaturan kelembagaan yang efektif seperti memiliki struktur organisasi, peran, } \\
\text { tugas, tanggung jawab yang jelas serta mampu menjalin networking dengan semua level } \\
\text { pemerintahan. }\end{array}$ \\
\hline Sumber Daya Manusia & $\begin{array}{l}\text { Memiliki sumber daya yang cukup disertai dengan pembagian pekerjaan dan delegasi } \\
\text { yang jelas }\end{array}$ \\
\hline Implementasi Kebijakan & $\begin{array}{l}\text { Tersedianya undang-undang, kebijakan dan peraturan sebagai landasan pengambilan } \\
\text { keputusan. Menjalin hubungan dengan institusi lainnya serta memobilisasi sumber } \\
\text { daya. }\end{array}$ \\
\hline Keuangan & $\begin{array}{l}\text { Memiliki dukungan keuangan yang memadai untuk mendukung semua aktifitas dalam } \\
\text { manajemen bencana. }\end{array}$ \\
\hline Kepemimpinan & $\begin{array}{l}\text { Memiliki kapasitas kepemimpinan yang dapat membaur keputusan yang cepat dan } \\
\text { tepat. }\end{array}$ \\
\hline
\end{tabular}

Sumber: diolah peneliti 
pemadaman yang kompatibel dengan kondisi lahan gambut (Prasetiyo, 2014). Ketiga, tradisi masyarakat membuka lahan dengan membakar lahan. Kebakaran-kebakaran yang tidak diinginkan dapat dikurangi dengan cara mendidik masyarakat secara proaktif (Moore, 2003; FAO, 2006). Partisipasi aktif masyarakat dalam upaya pencegahan kebakaran di desa sangat penting. Hal tersebut juga perlu didukung dengan pelaksana/fasilitator yang memahami budaya lokal (Linchang et al, 2001; Berkat, 2007).

Faktor-faktor tantangan diuraikan menjadi dua yakni, jenis tanah gambut dan perubahan iklim. Pertama, Provinsi Riau merupakan provinsi dengan struktur lahan lebih dari 50 persen lahan gambut wilayah pulau Sumatera. Penggolongan lahan gambut dikategorikan menjadi tiga kelompok kondisi gambut yaitu lahan gambut tidak tergenang permanen dalam kondisi asli, lahan gambut tidak tergenang permanen dan dimanfaatkan serta lahan non-gambut (tanah mineral). Provinsi Riau didominasi lahan gambut tidak tergenang permanen, yang dimanfaatkan untuk Hutan Tanaman Industri (HTI), perkebunan, lahan pertanian dan lain-lain. Kedua, laju pertumbuhan ekonomi di Riau. Perkiraan bahwa faktor ekonomi memiliki keterkaitan dengan perubahan iklim. Hal ini merupakan bentuk singgungan yang ditujukan kepada pembuat kebijakan mengenai pentingnya hubungan antara hutan dan iklim. Di Indonesia strategi pembangunan hutan lebih diarahkan pada pertumbuhan ekonomi yang tinggi (Nandika, 2005). Faktor geografis yaitu jarak antar kabupaten di Riau yang berjauhan, menjadi tantangan tersendiri terlebih ketika keterbatasan alat tidak mendapatkan solusi.

\section{Kapabilitas Pemerintah Daerah Provinsi Riau dalam Pengendalian Kebakaran Hutan dan Lahan Penyebab Kabut Asap}

Kapabilitas organisasi lebih dari sekedar sumber daya manusia tapi juga menyangkut "sistem" dan "proses". Proses dan sistem yang dibentuk oleh Pemerintah Provinsi Riau bertanggung jawab dalam upaya pencegahan kebakaran hutan dan lahan, yakni membentuk Pusat Pengendalian Kebakaran Hutan dan Lahan (PUSDALKARHUTLA). Perkembangannya, PUSDALKARHUTLA berubah menjadi BPBD yang membentuk pos komando. Namun dari keseluruhan sistem dan proses yang berlaku, kapabilitas yang dikerjakan selama ini berhenti pada pengendalian kabut asap yaitu pemadaman api secepatnya.

Pola diatas merupakan hasil analisis yang didapatkan dari telaah referensi jurnal, hasil penelitian sebelumnya dan temuan lapangan mengenai keadaan pola sistem pengendalian yang dilaksanakan oleh pemerintah Provinsi Riau. Kotak ketiga merupakan output yang didapatkan ketika kapabilitas dilaksanakan dengan baik. Kotak pertama dan kedua berjalan terus menerus hanya saja sesuai dengan paparan sebelumnya, dipertegas pada paragraf selanjutnya pada bab ini. Pola yang dijalakan selama ini hanya terfokus dalam pengendalian api agar kabut asap tidak menebal, serta bagaimana upaya memadamkan

\section{Gambar 1. \\ Pola Kapabilitas}

\begin{tabular}{|c|c|c|c|}
\hline $\begin{array}{c}\text { Bagian dari } \\
\text { penyempurnaan } \\
\text { semua dimensi } \\
\text { pendukungnya }\end{array}$ & $\begin{array}{c}\text { Memenuhi kebutuhan } \\
\text { Sistem } \\
\text { dalam mewujudkan } \\
\text { sebuah kapabilitas yang } \\
\text { baik }\end{array}$ \\
\cline { 2 - 2 }
\end{tabular}

Sumber: diolah peneliti 
api. Diperlukan pemahaman dan analisis yang baik, sehingga pola kapabilitas Pemerintah Provinsi Riau mencapai tujuan utama, yaitu bagaimana mengendalikan kebakaran hutan dan lahan.

Pengendalian membutuhkan sistematika yang tersusun rapi untuk mencapai tujuan. Pengendalian kebakaran hutan dan lahan sendiri dimulai dalam tiga tahapan yaitu pencegahan, penanggulangan (pemadaman) serta pemulihan sesuai cerminan yang terdapat dalam Peraturan Gubernur Nomor 11 Tahun 2014 tentang Pusat Pengendalian Kebakaran Hutan dan Lahan Provinsi Riau yang kemudian disempurnakan dengan Peraturan Gubernur Riau Nomor 27 Tahun 2014 tentang Prosedur Tetap Pengendalian Bencana Asap Akibat Kebakaran Hutan dan Lahan di Provinsi Riau. Ketiga tahapan tersebut mutlak menjadi tahapan yang harus dilaksanakan oleh Pemerintah Provinsi Riau beserta jajarannya yang terlibat dalam usaha pengendalian kebakaran hutan dan lahan di Riau.

Penelitian ini menunjukkan tahapan yang dilakukan oleh jajaran Pemerintah Provinsi Riau hanya pada tahapan penanggulangan (pemadaman) kebakaran hutan dan lahan. Meskipun bentuk tim/organisasi yang terlibat dalam pengendalian kebakaran hutan dan lahan lengkap dengan tugas dan bidang satuan kerja, namun aksi yang dilakukan selalu terhenti pada agenda pemadaman. Koordinator pelaksana pun ditujukan pada BPBD Provinsi Riau. Peraturan Gubernur yang diberlakukan sebagai pedoman pelaksanaan pun menekankan pada dampak kebakaran yaitu kabut asap. Sama halnya seperti yang diutarakan S. Robert Aiken (2004), dalam penelitiannya kebakaran hutan dan lahan yang terjadi di Indonesia bukan sepenuhnya karena api, tapi ketidak sesuaian kebijakan penggunaan lahan dengan praktiknya. Peranan pemerintah dalam menentukan sebuah kebijakan menjadi arahan bagi aktor pelaksananya. Sensitivitas pemerintah begitu mendominasi untuk menghasilkan arah pengendalian terhadap kebakaran hutan dan lahan yang selama ini terjadi di Riau.

Kapabilitas yang baik mampu mencakup keseluruhan tahap pengendalian kebakaran sehingga tujuan utama dari pengendalian dapat terealisasi. Kebakaran yang terjadi berulang kali melalui pandangan awam mengindikasikan terdapat masalah dalam kapabilitas yang dilakukan oleh Pemerintah Riau selama ini. Sebagaimana yang dikemukakan oleh Screyogg \& Kliesch Eberl,

"menyelesaikan tugas yang kompleks
memerlukan kemampuan dengan
kapasitas yang luas. Kapabilitas adalah
kemampuan organisasi untuk berubah
dan mengembangkan prasyarat penting
dengan cepat untuk mempertahankan
keunggulan kompetitif",

Dibutuhkan pemahaman yang baik oleh aktor pelaksana terhadap tugas dan tujuan pekerjaan yang harus dicapai dalam sebuah kapabilitas Pemerintah Provinsi Riau.

Kusumasari (2014), menghubungkan kapabilitas pemerintah dan faktor penting didalam pelaksanaan, yaitu kelembagaan, sumber daya manusia, implementasi kebijakan, keuangan dan kepemimpinan. Berikut penjabaran yang ditemukan peneliti dilapangan yang disesuaikan dengan penjelasan tersebut.

Kelembagaan, dengan faktor penting yang terkandung dalamnya memerlukan pengaturan kelembagaan yang efektif seperti memiliki struktur organisasi, peran, tugas, tanggung jawab yang jelas serta mampu menjalin networking dengan semua level pemerintahan. Sistem yang dibentuk oleh Pemerintah Provinsi Riau untuk mengendalikan kebakaran yang terjadi sudah tersusun dengan struktur sesuai peran setiap aktor tiap bidang. Masalah networking tidak bisa berjalan karena tidak merangkul jajaran pemerintah provinsi level tertinggi hingga terendah dengan baik, 
termasuk dalam kesamaan kompetensi yang dimiliki untuk mendukung terciptanya iklim networking.

Sejalan dengan hal tersebut menurut Hatch \& Cunliffe (2006) pengaturan kelembagaan tersebut akan selalu membentuk tindakan seperti apa yang akan dilaksanakan oleh pejabat publik. Pengaturan yang menjadi patokan dalam kelembagaan pengendalian kebakaran hutan dan lahan di Riau mengarah kepada pengendalian bencana kabut asap, bukan pada kebakaran yang terjadi, sehingga pekerjaan yang dilakukan berjalan pada penanggulangan (pemadaman) saja. Hal ini terjadi hingga level terkecil pemerintahan dan Masyarakat Peduli Api (MPA). Masyarakat Peduli Api merupakan komunitas masyarakat setempat yang dibentuk oleh tim BPBD (sebelumnya PUSDALKARHUTLA), sebagai bentuk sosialisasi pemerintah untuk memberi pemahaman dampak jika membakar hutan. Masyarakat peduli api dibimbing dan diberi peralatan sebagai bentuk pertolongan pertama jika terjadi kebakaran lahan disekitar mereka.

Rekonstruksi dari kelembagaan yang terbentuk memang telah mengalami perubahan dalam pola. Terbukti dengan dilakukannya rencana aksi, pemantapan struktur organisasi, serta membentuk komunitas masyarakat yang dekat dengan lokasi yang kerap terbakar. Hal ini sudah sejalan dengan yang dikemukakan oleh Selzinck (1957), kelembagaan merupakan sebuah proses yang terjadi pada organisasi dari masa ke masa. Beragam pembenahan telah dilakukan, namun pertanyaan mendasar ketika perubahan dan penyesuaian telah dilakukan, mengapa kebakaran dan kabut asap muncul kembali? Terdapat dasar manajemen yang dilakukan selama ini, yakni penanggulangan (pemadaman saja).

Keselarasan kualitas sumber daya manusia yang mendukung suksesnya pengendalian belum memiliki standar antara provinsi dan kabupaten. Peralatan lengkap berada di Pekanbaru, sementara kebakaran hutan dan lahan berada di wilayah Kabupaten. Kurangnya upaya peningkatan yang dilakukan oleh Pemda Riau, pemahaman dasar dalam paragraf ini tidak berbicara jumlah tenaga yang memadamkan (tahap penanggulangan) saja, namun pengendalian yang dilakukan secara utuh. Sebagaimana dikemukakan Sedarmayanti (2004), perlu ada upaya peningkatan SDM, termasuk penajaman daya nalar, keterampilan, penguasaan ilmu serta teknologi.

Perspektif mikro menurut Flippo (dalam Handoko 1994), sumber daya manusia meliputi perencanaan, pengorganisasian, pengarahan dan pengawasan kegiatan-kegiatan pengadaan, pengembangan, pemberian kompensasi, pengintegrasian, pemeliharaan yang menyeluruh untuk mencapai tujuan. Perencanaan yang dilakukan memang dengan tahapan terstandar yang menjadi patokan namun pengawasan sepertinya dilupakan oleh Pemda Riau. Seperti dilansir media dan kasus yang sudah terbukti sebelumnya bahwa kebakaran yang terjadi selama ini merupakan unsur kesengajaan yang dilakukan baik masyarakat, pengusaha maupun korporasi konsesi perkebunan di Riau. Tindak lanjut dari masalah penegakan hukum yang dilakukan (juga arah yang harus dituju dalam dimensi kelembagaan) yaitu mengkaji kembali IUP (Izin Usaha Perkebunan) yang ada, termasuk pembekuan izin ataupun ketegasan dari Pemda Riau untuk pencabutan izin jika memang pantas diberlakukan. Pengawasan izin setiap IUP perusahaan belum secara utuh menjadi tahapan dalam tuntutan manajemen SDM pengendalian kebakaran hutan dan lahan di Riau.

Dimensi implementasi kebijakan yang terjadi dalam kapabilitas Pemerintah Provinsi Riau menjalankan amanat Peraturan Gubernur Riau Nomor 27 Tahun 2014 tentang Prosedur Tetap Pengendalian Bencana Kabut Asap akibat Kebakaran Hutan dan Lahan di Riau, untuk memobilisasi sumber daya manusia yang ada dalam bekerja sesuai dengan struktur yang telah 
ditetapkan. Seperti yang telah dikemukakan oleh Grindel (dalam Nugroho, 2009), setiap peraturan yang dibentuk, bergantung bagaimana implementasi dilakukan oleh aktor pelaksana. Posko Gabungan merupakan bentuk tindakan yang dilakukan oleh Pemerintah Provinsi Riau, penyatuan semua aktor yang terlibat dengan harapan terjalin networking yang baik dan komunikasi yang selaras. Jika mencermati konten dari kebijakan (Peraturan Gubernur) yang berlaku, memang mengacu pada pengendalian bencana kabut asap, komunikasi yang dibentuk masih kurang, karena perbedaan kompetensi yang bekerja pada semua level pemerintahan dengan tiga tahapan pengendalian yang harus dipenuhi.

Pada dasarnya implementasi yang dilakukan setiap tahapan sudah dilakukan sesuai anggaran. Namun timbul pertanyaan ketika implementasi sudah dilakukan, mengapa kebakaran masih terjadi berulang kali? Asumsinya adalah apakah desain dari kebijakan sudah sesuai? Jika hanya terfokus pada pengendalian bencana kabut asap, sementara dasar kabut asap ada pada kebakaran, maka seharusnya fokus menyeluruh dalam tahapan ada pada pengendalian kebakaran hutan dan lahan.

Sejalan yang diungkapkan oleh Ripley dan Franklin, terbentuknya posko gabungan, aktor yang bertugas memiliki tanggung jawab pada tiap bidang, namun tidak diimbangi dengan sisi anggaran yang mencukupi menjadi salah satu kendala, karena Riau tidak memiliki alokasi dana khusus untuk operasional kegiatan pengendalian.

Dimensi keuangan merupakan satu hal yang mendukung kebijakan pemerintah, seperti yang dituangkan dalam Peraturan Pemerintah Nomor 58 Tahun 2005 yaitu APBD. Ketika Riau tidak memiliki alokasi khusus untuk menjalankan tugas pengendalian kebakaran hutan dan lahan, semua biaya operasional ditutupi oleh anggaran yang dialokasikan oleh SKPD yang terlibat untuk membiayai operasional masing-masing. Sementara untuk posko gabungan dibiayai oleh pusat lewat BNPB dan tidak mampu menutupi biaya harian operasional maupun untuk SDM yang bekerja. Dimensi keuangan begitu lemah karena daerah Riau tidak memiliki dana mandiri untuk mencapai tujuan dari peningkatan kapabilitas dalam mengendalikan kebakaran hutan dan lahan.

Faktor kepemimpinan tidak terlepas dari kepentingan politik di lingkungan pemerintahan. Mengarah kepada Peraturan Pemerintah Nomor 72 Tahun 2005 pejabat kepala desa memiliki hak dalam mewakili desanya. Setiap pergerakan yang terjadi di daerahnya menjadi pengetahuan kepala desa, yang akan dilanjutkan pada tingkatan selanjutnya sampai pada level tertinggi kepemimpinan di daerah yaitu Gubernur. Tiga gubernur terakhir Riau, memiliki pola berbeda pada gaya memimpin dan mempengaruhi orang-orang sekitarnya.

Tahun 2007 dan 2012 merupakan tahun Riau bebas asap. Keadaan ini merefleksikan apa yang disebutkan oleh Rost (1993), kepemimpinan sebuah hubungan yang saling mempengaruhi antara pemimpin dan pengikut (bawahan) yang menginginkan perubahan nyata yang mencermin tujuan bersamanya. Saat itu Riau menjadi tuan rumah acara PON Riau 2012, Gubernur Riau mengisyarakatkan kepada jajarannya bahwa Riau harus bebas kabut asap. Tahun 2007 Kapolda Riau gencar menangani praktik illegal logging. Begitu besar pengaruh yang diberikan oleh pemimpin untuk menginstruksikan kepada bawahan. Esensinya, bukan hanya fakor kepemimpinan yang dibutuhkan, karena ada kepentingan yang bersifat jangka pendek. Keseriusan yang baik akan mampu menciptakan suasana pemimpin dan bawahan yang mampu mencapai tujuan.

Politik menjadi konsep lain yang muncul dalam dimensi kapabilitas kelembagaan. Tahun 2014 Riau pada status darurat bencana kabut asap pada kepemimpinan Anaas 
Maamun yang disinyalir tidak memiliki cukup pengalaman, dengan hanya memimpin Kabupaten Rokan Hilir sebelumnya. Selain itu konsesi yang terbakar berada dikabupaten Rokan Hilir memiliki hubungan dengan Anaas Maamun. Bukan rahasia lagi bagi perangkat pemerintah daerah Kabupaten Rokan Hilir Riau. Kekuasaan politik ikut bekerja dalam dimensi kepemimpinan untuk menghasilkan kapabilitas pengendalian kebakaran hutan dan lahan di Riau, yang mengarah kepada kepentingan pribadi. Realitas politik yang berubah dan kompleks, menimbulkan analisis dalam pemikiran peneliti. Tesis ini merupakan naskah akademik, penulisannya menggunakan konsep yang jelas sebagai dasar analisis. Hal ini sejalan dengan studi yang dilakukan oleh Donald Rotchild dan Robert Curry dalam Rachbini (2006) menjelaskan adanya hubungan kepentingan individu dengan kepentingan publik.

\section{Pengaruh Hambatan dan Tantangan dalam Kapabilitas Pengendalian Kebakaran Hutan dan Lahan untuk Pemerintah Provinsi Riau}

Hambatan memunculkan tiga faktor yaitu pembagian wewenang kawasan kehutanan, keterbatasan alat dan tradisi masyarakat lokal dalam membuka lahan baru. Analisis ketiga faktor ini dalam pemikiran peneliti yaitu kawasan kehutanan untuk faktor yang pertama memberi pengaruh dalam hambatan. Analisisnya adalah masalah perizinan merupakan hal adminstratif yang harus dijelaskan oleh pemerintah, terlebih kewenangan dimulai dari pemerintah daerah. Banyaknya perusahaan yang belum memiliki izin usaha mengindikasikan bahwa pemerintah Provinsi Riau tidak memiliki sikap tegas mengingat masalah kebakaran terjadi pada setiap tahun. Riau dengan kabut asap selalu hadir setiap tahun, tidak memiliki penguatan sebagai garda depan untuk mempersiapkan dan melaksanakan serta mengevaluasi kebakaran hutan dan lahan. Pemerintah telah bertindak namun efek nyata tidak sampai kepada sasaran. Hal ini sama seperti penyampaian Kogoya (2014), garda depan yang baik menjadi faktor sampainya tujuan sebuah organisasi.

Pemerintah Provinsi Riau berjalan berdampingan dengan NGO. Seperti umumnya NGO yang bergerak pada bidang lingkungan, mereka mengamati perjalanan kebijakan dan prosedur yang selama ini telah dilakukan oleh Pemerintah Riau. Namun keberadaan NGO tidak memiliki signifikansi tersendiri untuk mengoreksi pekerjaan yang telah dilakukan oleh pemerintah Provinsi Riau. Hal ini pun dibetulkan oleh WALHI. Sebagaimana dipaparkan oleh Mukhopadhyay (2001), penempatan LSM yang berkompenten dapat memberikan pengetahuan yang mendukung pemerintah.

Hambatan yang kedua adalah keterbatasan alat, Riau "tidak memiliki peralatan yang memenuhi standar yang dibutuhkan dalam periodik kebakaran hutan dan lahan yang terjadi seperti saat ini". Alat disini bukan seperangkat alat pemadam sederhana, karena bicara kebakaran Riau berarti terhubung dengan gambut yang apabila terbakar dibutuhkan treatment dan penanganan khusus. Alokasi untuk penyediaan alat pun tidak dimiliki. Penyediaan alat berhubungan dengan faktor geografis, karena kelengkapan alat yang merata dan tuntutan tanggung jawab pemilik konsesi. Peralatan yang digunakan dalam posko gabungan merupakan bentuk bantuan dari BNPB, yang sifatnya sementara. Hal ini merangkum apa yang dipaparkan oleh Prasetiyo (2014), bahwa sangat diperlukan peralatan yang kompatibel dengan lahan gambut, karena jika tidak sesuai penyediaan peralatan hanya sia-sia dan membuang anggaran.

Hambatan ketiga, tradisi masyarakat membuka lahan dengan membakar hutan karena dianggap bisa menyuburkan tanah. Namun pembakaran lahan tersebut berubah 
menjadi kesengajaan karena metode membakar dianggap menghemat biaya yang dikeluarkan serta waktu dalam proses land clearing. Seperti yang diungkapkan oleh Linchang et al, 2001 dalam Berkat (2007) partisipasi masyarakat merupakan metode terampuh dalam mencegah terjadi kebakaran, namun ketika masyarakat sendiri yang menjadi oknum baik untuk kepentingan pribadi dan suruhan korporasi perusahaan maka kebakaran menjadi hal yang mudah terjadi.

Tantangan saat ini dan kedepan soal kapabilitas pemerintah dalam melakukan pengendalian kebakaran hutan dan lahan adalah perubahan iklim, laju pertumbuhan ekonomi di Riau dan faktor geografis. Ketiga faktor ini adalah faktor umum yang akan selalu menjadi tantangan Pemerintah Provinsi Riau. Namun menurut peneliti, ketiga faktor tersebut dapat disederhanakan, tentu dengan kerja keras dan keseriusan dalam mengambil kebijakan serta tindakan yang selalu di evaluasi untuk penyesuaian kebutuhan yang terjadi.

Lahan gambut dan perubahan iklim merupakan keadaan yang bersifat given, karena Riau memiliki struktur 50 persen tanah gambut Pulau Sumatera. Perubahan iklim merupakan fenomena alam yang memiliki siklus mendasar. Perilaku manusialah yang membuat alam terkadang bekerja tidak seperti siklus sebenarnya (kerusakan lingkungan yang disebabkan prilaku manusia). Finger (2006) menyebutkan pula kebijakan yang gagal menyebabkan perubahan iklim dan global warming terjadi. Serta tata kelola sumber daya alam Riau yang tidak teratur menjadi kontribusi terbakarnya lahan gambut, karena diduduki oleh perusahaan konsesi seperti kelapa sawit dan akasia. Maka adaptasi sebagai bentuk solusi yang harus disiasati oleh Pemerintah Provinsi Riau dalam upaya nya menata tata kelola sumber daya alam.

Gambutyang terbakar tidakmenimbulkan masalah dalam kabut asap yang dihasilkan sepanjang bukan berada di musim kemarau.
Hal ini sesuai dengan apa yang telah dijabarkan oleh Surati Jaya, 2006, dalam Endarmiyati (2009). Maka tantangan ini dapat disederhanakan oleh pemerintah jika dapat merumuskan sebuah kebijakan berbasis lingkungan hidup yang tepat, dengan menempatkan SDM berkompetensi tinggi pada bidang gambut.

Solusi lain adalah mengenal lahan gambut dan melakukan inovasi mengenai tanaman yang mampu menggerakan ekonomi, tanpa harus merusak gambut dengan membakar ataupun mengeringkan lahan. Misalnya menanam sagu. Pada dasarnya sagu merupakan komoditi cocok tanam masyarakat lokal sejak dahulu sebelum kelapa sawit ataupun akasia berkembang pesat di Riau. Namun adaptasi lingkungan hidup dan penataannya perlu peran dan konsistensi dari Pemerintah Provinsi Riau.

Faktor pertumbuhan ekonomi begitu pesat dan pertumbuhan areal konsesi di Riau, serta letak Riau yang strategis (berdekatan dengan Singapura dan Malaysia) menjadikan Riau bak mutiara karena potensi keuntungan yang akan dihasilkan ketika berinvestasi di Riau. Samuelson \& Nordhaus (2004) menyatakan hal yang serupa dalam empat faktor penumbuhan ekonomi untuk meningkatkan investasi. Salah satunya adalah dengan adanya sumber daya alam yang mendukung (Oktaviany, 2011). Namun keseluruhannya kontrol oleh pemerintah sangat perlu dikuatkan. Terbukti dalam kasus kebakaran beberapa tahun terakhir, pemerintah Provinsi Riau belum melakukan sweeping terhadap pelaku usaha konsesi maupun korporasi konsesi yang berada di Riau dalam kelengkapan izin, pengawasan izin dan memperketat izin konsesi yang lebih ekstrem dalam pembekuan izin usaha perkebunan.

Sama halnya dengan gambut dan perubahan iklim, faktor geografis merupakan hal yang bersifat given, penyiasatan geografis akan berjalan baik jika hambatan dalam kelengkapan alat dapat terpenuhi oleh Pemerintah Provinsi Riau. Geografi merupakan 
tantangan yang menjadi pengaruh dalam kapabilitas Pemerintah Provinsi Riau, jarak yang begitu jauh untuk ditempuh ditambah keterbatasan alat yang dimiliki oleh pemerintah kabupaten tidak dapat menyelesaikan masalah kebakaran hutan dan lahan.

\section{Kesimpulan}

Pertama, kapabilitas Pemerintah Provinsi Riau dalam pengendalian kebakaran hutan dan lahan belum berjalan dengan efektif. Penelitian ini menemukan bahwa pengendalian kebakaran hutan dan lahan lahan pemerintah Provinsi Riau mengarah kepada pemadaman untuk mencegah terjadinya kabut asap. Seharusnya pengendalian memiliki tiga tahapan yaitu pengendalian, pemadaman dan pencegahan serta dilakukan pemantauan. Tahapan pemadaman saja yang menjadi acuan dalam pengendalian yang dilakukan oleh Pemerintah Provinsi Riau, sehingga kapabilitas yang ingin dicapai tidak selesai pada tujuannya. Wajar saja kebakaran hutan dan lahan terjadi berulang-ulang, ditambah dengan manajemen sumber daya alam yang tidak tertata dengan baik, lahan gambut yang diduduki oleh perusahaan konsesi serta data Polda Riau pun mengindikasi unsur kesengajaan dari perusahaan dalam membakar lahan.

Hal tersebut terlihat dari aspek kelembagaan tidak memiliki networking baik yang dijalin antara instansi yang ada di Pemerintah Provinsi maupun Pemerintahan Kabupaten. Satuan kerja yang terlibat tidak menyelesaikan tugas pada fungsi masingmasing karena semua berkumpul dan terlibat kepada pemadaman kabut asap. Dimensi kapabilitas yang kedua yaitu sumber daya manusia yang bukan berbicara jumlah kuantitas saja, namun kualitas terhadap bidang masingmasing. Tidak memiliki kesamaan antara tingkat provinsi dan kabupaten, serta selama ini tidak menempatkan orang yang memang memiliki potensi sesuai dengan masalah yang terjadi. Selanjutnya implementasi kebijakan yang menjadi tolak ukur adalah Peraturan Gubernur mengenai pengendalian kabut asap, sehingga fokus yang dijalankan secara keseluruhan adalah kabut asap agar tidak memburuk, bukan kepada kebakaran hutan dan lahan. Hal tersebut diperparah dengan penataan tata ruang dan tata kelola sumber daya alam yang buruk karena tidak memiliki aturan baku.

Dimensikeuanganyanghanyabergantung kepada dana pusat, karena Riau tidak memiliki alokasi anggaran khusus baik untuk operasional pengendalian kebakaran hutan dan lahan maupun anggaran yang dialokasikan untuk peralatan. Kepemimpinan pun mempengaruhi pengendalian kebakaran hutan dan lahan. Pada tahun 2007 dan 2012 merupakan era Riau bebas kabut asap karena Kapolda saat itu yang gencar dalam masalah illegal logging dan Gubernur yang mempersiapkan PON Riau. Politik kepemimpinan bermain dari level terbawah dari mulai perizinan karena sudah melibatkan pemerintahan tingkat kabupaten. Hal tersebutlah yang mendukung kapabilitas pemerintah Riau menyelesaikan masalah pengendalian kebakaran hutan dan lahan. Meski penyempurnaan sistem pengendalian yang dibentuk sudah semakin terpadu dengan baik namun sasarannya tidak sampai kepada pengendalian kebakaran hutan dan lahan.

Kedua, Faktor-faktor hambatan dan tantangan yang dapat dirinci sebagai berikut:

1. Hambatan yang memberi pengaruh dalam kapabilitas Pemerintah Provinsi Riau didalam pengendalian kebakaran hutan dan lahan.

Pemerintah tidak mampu menyiasati dan memberi solusi dari hambatan serta tantangan yang memang sudah bersifat given, sehingga perlu adanya bentuk adaptasi untuk memberi solusi terhadap keadaan yang terjadi. Hambatan seperti pembagian kawasan kehutanan yang sudah lemah mengenai perizinan, ranah pemerintah yang dimulai dari sisi perizinan, 
tidak didukung dengan peraturan mengenai pembagian kawasan hutan yang dapat dijadikan lahan perkebunan, kemudian keterbatasan alat yang dimiliki oleh pemerintah provinsi maupun kabupaten. Pada dasarnya pemerintah mensyaratkan kepada perusahaan untuk melengkapi sistem pendeteksi kebakaran dan peralatan pendukung. Kenyataannya selain tidak terkontrol dengan baik ternyata banyak perusahaan yang tidak memiliki istem pendeteksi kebakaran dan peralatan pendukung. Hambatan yang ketiga yaitu tradisi membakar untuk skala masyarakat sudah dirangkul hingga membentuk Masyarakat Peduli Api (MPA). Namun masih saja pengusaha konsesi menggunakan metode membakar ketika pembersihan lahan karena mampu menghemat pengeluaran operasional perusahaan. Masalahnya lahan yang mereka bakar adalah lahan gambut yang sulit dipadamkan ketika terbakar.

2. Faktor-faktor yang menjadi tantangan dalam kapabilitas pemerintah Provinsi Riau dalam pengendalian kebakaran hutan dan lahan.

Pengaruh faktor tantangan lahan gambut yang bersifat given dan perubahan iklim yang terjadi, perlu dilakukan adaptasi bagi pemerintah jika memang ingin tetap memanfaatkan lahan gambut. Hanya satu wilayah kabupaten di Riau yaitu Meranti yang melakukan adaptasi terhadap lahan gambut dengan menyesuaikan wilayahnya dengan jenis tanaman yang bersahabat dengan lahan gambut. Laju pertumbuhan ekonomi Riau dapat dilanjutkan dengan baikjika tata kelola gambut dapat diperbaiki. Tantangan terakhir yaitu faktor geografis antar kabupaten yang tidak akan selesai jika keterbatasan alat tidak terpenuhi, karena jarak antar kabupaten di Riau cukup jauh.

\section{Daftar Pustaka}

Aditjonoro, George Junus. (2003). KebohonganKebohongan Negara, Prihal Kondisi Obyektif Lingkungan Hidup Di Nusantara. Yogyakarta: Pustaka Pelajar.

Aditjonoro, George Junus. (2003). KorbanKorban Pembangunan, Tilikan terhadap Beberapa Kasus Perusakan Lingkungan di Tanah Air. Yogyakarta: Pustaka Pelajar.

Aiken. S Robert. (2004). Runway Fires, SmokeHaze Pollution, and Unnatural Disaster in Indonesia. Geographical Review, Vol. 94, No. 1; American Geographical Society.

Asdak, Chay. (2012). Kajian Lingkungan Hidup Strategis: Jalan Menuju Pembangunan Berkelanjutan. Yogyakarta: Gadjah Mada University Press.

Astuti, Rini. (2013). REDD+ sebagai StrategiStrategi Kepengaturan dalam Tata Kelola Hutan di Indonesia; Sebuah Perspektif Foucauldian. Jurnal Transformasi Sosial WACANA, No. 30 Tahun XV. Insist Pers: Yogyakarta.

Bovaird, R. \& Wittmer, H. (2006). Public Private Partnership: From Contested Concepts to Prevalent Practice. International Review of Administrative Science, 72 (4): 199-215.

Cresswell, John W. (2012). Research Design : Pendekatan Kualitatif, Kuantitatif, dan Mixed. Yogyakarta : Pustaka Pelajar.

Depoorte, Ben. (2006). Horizontal Political Externalities: The Supply And Demand Of Disaster Management. Duke Law Journal, Vol 56, No.1, Thirty-Sixth Annual Administrative Law Issue.

Dwiyanto, Agus. (2012). Manajemen Pelayanan Publik: Peduli, Inklusif dan Kolaboratif. Yogyakarta: Gadjah Mada University Press.

Endarmiyati, (2009). Zonasi Kerawanan Kebakaran Hutan dan Lahan Beserta Strategi Pencegahannya di Kabupaten Siak Provinsi Riau. Tesis Universitas Gadjah Mada tidak diterbitkan. Yogyakarta. 
Fauzi, (2004). Ekonomi Sumber Daya Alam dan Lingkungan: Teori dan Aplikasi. Jakarta: Gramedia Pustaka Utama.

Fiedler, Fred E. (1967). A Theory of Leadership Effetiveness. New York: Mc Graw-Hill.

Harnden, Boyd M., Maher, P, Michael,. Martin, Gregory A. (1973). Forest Fire Detection Systems Design. Management Science, Vol. 20, No. 4 Desember 1973. USA.

Heywood, Andrew. (2014). Politik. Yogyakarta: Pustaka Pelajar.

Ivancevich, John M., Konopaske, Robert., Matteson, Michael T. (2006). Perilaku dan Manajemen Organisasi, Edisi Ketujuh, Jilid 2. Jakarta: Erlangga.

Kanninen, Markku., Dkk. (2009). Apakah Hutan Dapat Tumbuh di Atas Uang? Implikasi Penelitian Deforestasi bagi Kebijakan yang Mendukung REDD+. Bogor CIFOR.

Kogoya, Lidea Fera. (2014). Kegagalan AATHP ASEAN dalam Menanggulangi Masalah Kebakaran Hutan dan Pencemaran Asap di Indonesia. Tesis UGM tidak diterbitkan. Yogyakarta.

Kusumasari, Bevaola. (2014). Manajemen Bencana dan Kapabilitas Pemerintah Lokal. Yogyakarta: Gava Media.

Larastiti, Ciptaningrat. (2013). Hidup di Antara Konsesi Hutan Gambut: Catatan Etnografis Desa Baun Bango. Jurnal Transformasi Sosial WACANA, No. 30Tahun XV. Yogyakarta: Insist Pers.

Leopold.L.B., F.E. Clarke., B.B. Hanshaw and J.R. Balsey. (1971). A Procedure for Evaluating Impact. Geological Survey Circular 645: Washington D.C.

Luis Gomez, Mejia. (2000). Moving Forward. Summer: HR News.

March and Olsen. (2005). Elaborating the New Institutionalism. Working Paper No. 11. March, 2005.

Mathis, Robert L., Jackson, John H. (2009). Human Resource Management. Jakarta: Salemba Empat.
Morita, Akira. (2013). Framework for Disaster Management: Planning and Reality. Tokyo: Gakushuin University.

Muslim, (2007). Aspek Hukum Upaya Pencegahan dan Penanggulangan Kebakaran Hutan dan atau Lahan diProvinsi Riau. TesisUniversitas Gadjah Mada tidak diterbitkan. Yogyakarta.

Nandika, Dodi. (2005). Hutan Bagi Ketahanan Nasional. Surakarta: Muhammadiah University Press.

N. Hyman, David. 2008. Public Finance: A Contemporary Application of Theory to Policy. South-Western: Mason.

Parsons, Wayne. (2005). Public Policy, Pengantar Teori dan Praktik Analis Kebijakan. Jakarta: Kencana.

Pasya, Kemal. (2013). Dilema Kelembagaan FormalInformal Mukim (Studi Kasus Pengelolaan dan Pemanfaatan Sumberdaya Hutan oleh Pemerintah Mukim Lambalek dan Panglima Uteun). Tesis Universitas Gadjah Mada tidak diterbitkan. Yogyakarta.

Purmono, Agus. (2012). Menjaga Hutan Kita, Pro-kontra Kebijakan Moratorium Hutan dan Gambut. Jakarta: Gramedia.

Purwanto, Erwan Agus., Sulistyastuti, Dyah Ratih. (2012). Implementasi Kebijakan Publik, Konsep dan Aplikasinya di Indonesia. Yogyakarta: Gava Media.

Rachbini. Didik. (2006). Ekonomi Politik dan Teori Pilihan Publik. Bogor: Ghalia Indonesia.

Riba, Clara., Ballart, Xavier. (2002). Forest Fire: Evaluation of Goverment Measures. Policy Scieces 35: 361-377,2002. Netherlands: Kluwer Academic Publisher.

Siagian, Sondang P. (1999). Manajemen Sumber Daya Manusia. Jakarta: Bumi Aksara.

Stern, Sir Nicholas. (2006). Stern Review: The Economics of Climate Change. Cambridge: Cambridge University.

Suharyanto, Hadriyanus., Hadna, Agus Heruanto. (2005). Manajemen Sumber Daya Manusia. Yogyakarta: Grha Guru dan Media Wacana. 
Sulistiyani, Ambar Teguh. (2008). Kepemimpinan Profesional, Pendekatan Leadership Games. Yogyakarta: Gava Media.

Suratmo, F. Gunawan. (2007). Analisis Mengenai Dampak Lingkungan. Yogyakarta: Gadjah Mada University Press.

Syahza,A. (2003). Paradigma Baru Pemasaran Produk Pertanian Berbasis Agribisnis di Daerah Riau. Jurnal Ekonomi, TH. VIII/01/Juni/2003, Hal 22-42, Jakarta: PPD\&I Fakultas Ekonomi Universitas Tarumanegara.

Tacconi, Luca., Jotzo, Frank., Grafton, R. Quentin. (2008). Local Causes, Regional Cooperation and global financing for enviromental problems: the case of Southeast Asian Haze Pollution. Int Environ Agreements 8:1-16.
Thoha, Miftah. (2003). Birokrasi Indonesia dalam Era Globalisasi. Jakarta: PD Batang Gadis.

Tsing, A.L. (2005). Friction: An Ethnography of Global Connection. Princeton dan Oxford: Princeton University Pers.

Usmara, A. (2003). Handbook of Organizations, Kajian dan Teori Organisasi. Yogyakarta: Amara Books.

Victor Vroom, Arthur Jago. (1995). Situation Effects and Levels of Analysis in the Study of Leader Participation. Spring: Leadership Quarterly.

Wijihastuti, Ratna. (2015). Implementasi Kebijakan Peningkatan Kapabilitas Aparat Pengawasan Intern Pemerintah (APIP) Pada Pemerintah Daerah di Wilayah Daerah Istimewa Yogyakarta. Tesis Universitas Gadjah Mada tidak diterbitkan. Yogyakarta. 